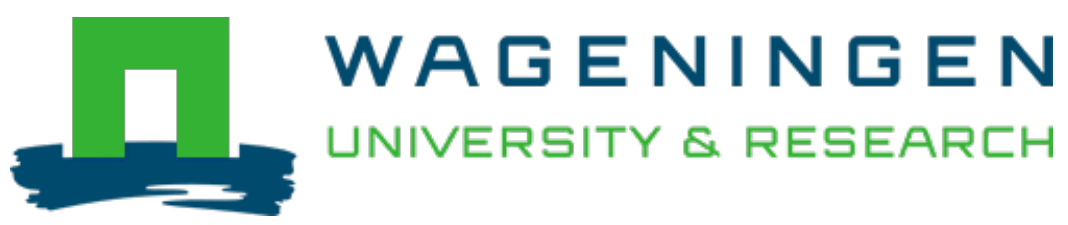

\title{
Effect of oxygen and carbon dioxide on germination and growth of Rhizopus oligosporus on model media and soya beans.
}

\author{
Applied Microbiology and Biotechnology \\ Reu, J.C.; Griffiths, A.M.; Rombouts, F.M.; Nout, M.J.R. \\ https://doi.org/10.1007/bf02431927
}

This publication is made publicly available in the institutional repository of Wageningen University and Research, under the terms of article $25 \mathrm{fa}$ of the Dutch Copyright Act, also known as the Amendment Taverne. This has been done with explicit consent by the author.

Article 25 fa states that the author of a short scientific work funded either wholly or partially by Dutch public funds is entitled to make that work publicly available for no consideration following a reasonable period of time after the work was first published, provided that clear reference is made to the source of the first publication of the work.

This publication is distributed under The Association of Universities in the Netherlands (VSNU) 'Article $25 \mathrm{fa}$ implementation' project. In this project research outputs of researchers employed by Dutch Universities that comply with the legal requirements of Article $25 \mathrm{fa}$ of the Dutch Copyright Act are distributed online and free of cost or other barriers in institutional repositories. Research outputs are distributed six months after their first online publication in the original published version and with proper attribution to the source of the original publication.

You are permitted to download and use the publication for personal purposes. All rights remain with the author(s) and / or copyright owner(s) of this work. Any use of the publication or parts of it other than authorised under article $25 \mathrm{fa}$ of the Dutch Copyright act is prohibited. Wageningen University \& Research and the author(s) of this publication shall not be held responsible or liable for any damages resulting from your (re)use of this publication.

For questions regarding the public availability of this publication please contact openscience.library@wur.nl 
J. C. de Reu · A. M. Griffiths

F. M. Rombouts - M. J. R. Nout

\section{Effect of oxygen and carbon dioxide on germination and growth of Rhizopus oligosporus on model media and soya beans}

Received: 5 August 1994/Received revision: 14 November 1994/Accepted: 5 December 1994

\begin{abstract}
The microcolony technique enables the effects of several atmospheric conditions on fungal growth to be studied by measuring the radius of the colony, while excluding effects of those conditions on germination of the sporangiospores. Various concentrations of oxygen and carbon dioxide in the gas environment were found to influence growth of Rhizopus oligosporus on malt extract/soya peptone/agar. The maximum radial growth rate was $1.48 \mathrm{~mm} / \mathrm{h}$ and the maximum specific growth rate was $0.109 \mathrm{~h}^{-1}$ at $30^{\circ} \mathrm{C}$. Oxygen became limiting below $1 \%(\mathrm{v} / \mathrm{v})$, but growth remained possible at levels of $0.001 \%$ oxygen. Carbon dioxide stimulated growth at limiting oxygen levels. The specific growth rate increased from $0.043 \mathrm{~h}^{-1}$ at $0.5 \%(\mathrm{v} / \mathrm{v})$ oxygen and $0 \%(\mathrm{v} / \mathrm{v})$ carbon dioxide to $0.096 \mathrm{~h}^{-1}$ at $0.5 \%(\mathrm{v} / \mathrm{v})$ oxygen and $5 \%(\mathrm{v} / \mathrm{v})$ carbon dioxide. A mixture of $0.5 \%(\mathrm{v} / \mathrm{v})$ oxygen and $35 \%(\mathrm{v} / \mathrm{v})$ carbon dioxide inhibited growth. Delay of sporangiospore germination due to low (less than $0.001 \%$ ) amounts of oxygen was not observed with the techniques used. Fungal activity in a rotating drum fermentor was more strongly affected by low levels of oxygen than was biomass formation on model media. High concentrations of carbon dioxide inhibited growth in the rotating drum fermentor at non-limiting levels of oxygen. It is concluded that aeration and heat removal are both essential aspects of optimization of large-scale solid-substrate bioreactors with $R h$. oligosporus.
\end{abstract}

\section{Introduction}

Solid-substrate fermentations are generally characterized by the growth of micro-organisms on water-insol-

J. C. de Reu (四) - A. M. Griffiths - F. M. Rombouts - M. J. R. Nout Department of Food Science, Wageningen Agricultural University (WAU), Bomenweg 2, $6703 \mathrm{HD}$ Wageningen, The Netherlands. Fax: + 31-8370-84893 uble substrates in the presence of varying amounts of free water (Mitchell and Lonsane 1992). Tempe is an example of a static solid-substrate fermentation, in which the inoculated soya beans are packed in 4- to 6 -cm-thick beds and covered with banana leaves or polyethylene sheets. Incubation takes $50-20 \mathrm{~h}$ at 25-37 ${ }^{\circ} \mathrm{C}$. Rhizopus spp. are considered to be essential for tempe making (Nout and Rombouts 1990). Rathbun and Shuler (1983) reported that, in tempe, oxygen levels decreased to approximately $2 \%(\mathrm{v} / \mathrm{v})$ and carbon dioxide increased to $22 \%(\mathrm{v} / \mathrm{v})$. The availability of oxygen and the removal of carbon dioxide are determined by diffusion, which in turn is determined by porosity, particle size and consistency of the substrate (AlvarezMartinez 1987; Mitchell et al. 1988). The effects of low concentrations of oxygen and high levels of carbon dioxide are not well described, but Hesseltine et al. (1985) and Soccol et al. (1994) reported that 16 and 19 different strains, respectively, of Rhizopus spp. were able to grow under anaerobic conditions.

The kinetics of microbial expansion were first analysed in depth by Pirt (1967). Trinci (1971) refined the model for colony growth of filamentous fungi. Initially growth is exponential and, this exponential expansion occurs until the colony diameter reaches about $0.2 \mathrm{~mm}$ (Trinci 1969). Exhaustion of nutrients beneath the centre of the colony causes growth inhibition in this region, and subsequently only the peripheral zone contributes to the radial expansion. The radial expansion of the fungal colony is:

$r_{\mathrm{t}}=\mu_{\mathrm{rad}} t+r_{0}$

where $r_{\mathrm{t}}=$ colony diameter at time $t(\mathrm{~mm}), \mu_{\mathrm{rad}}=$ radial growth rate $(\mathrm{mm} / \mathrm{h})$ and $r_{0}=$ colony radius after inoculation $(\mathrm{mm})$.

This simple model (Eq. 1) describes the radial expansion of fungal colonies but it cannot describe the kinetics of biomass production since it ignores the variations of mycelial density occurring in the zone behind he peripheral growth zone. 
At a macroscopic level, the value of the specific growth rate $\left(\mu_{\mathrm{x}}\right)$ has been estimated using empirical equations based on phenomenological parameters, i.e. the maximum specific rate of growth, $\mu_{\max }$, and the maximum biomass density, $X_{\mathrm{m}}$, in the "logistic equation" (Eq. 2). This approach has been used to describe the fungal growth curves in liquid or solid substrates (Okazaki et al. 1980; Oriol et al. 1987).

$\mu_{\mathrm{x}}=\mu_{\max }\left[1-\frac{X}{X_{\mathrm{m}}}\right]$

The aim of this study is to determine and to model the effects of oxygen and carbon dioxide on germination and growth of Rhizopus oligosporus NRRL 5905 during incubation on malt extract/soya peptone/agar plates in order to evaluate the comparative importance of control of heat removal and gaseous atmosphere composition.

\section{Materials and methods}

\section{Culture}

Rhizopus oligosporus NRRL 5905 was grown and maintained on malt extract agar (Oxoid CM59) slants. Sporangiospore suspensions were prepared as described previously (de Reu et al. 1993). The viable count varied between $1 \times 10^{6}$ and $5 \times 10^{6}$ colony-forming units/ml.

Incubator

A purpose-built (WAU engineering workshop) aerated air-tight incubator $(70 \times 40 \times 40 \mathrm{~cm}$, length $\times$ depth $\times$ height $)$ was connected to a multi-gas controller (MKS, Münich, Germany) which controlled four mass-flow controllers $(10,100,1000$ and 2000 standard cubic centimetres per minute, MKS, Münich, Germany). Gas mixtures consisting of various proportions of oxygen, carbon dioxide and nitrogen were humidified to $100 \%$ before entering the incubator. The flow rate was set at $1.0 \mathrm{l} / \mathrm{min}$. Non-inoculated petri dishes were placed in the incubator to equilibrate with the gas atmosphere for $4 \mathrm{~h}$ before the inoculation took place. During the experiments the petri dishes were removed without disturbing the gas atmosphere of the incubator, by using a small lock. The incubation temperature was set and controlled at $30 \pm 0.5^{\circ} \mathrm{C}$.

\section{Inoculation}

\section{Micro-colony}

A 1-ml sample of a 1000 -fold diluted sporangiospore suspension was used in pour plates with malt extract $(100 \mathrm{~g} / \mathrm{l}$, Oxoid), soya peptone $(50 \mathrm{~g} / 1$, Oxoid) and technical agar $(1 \% \mathrm{w} / \mathrm{v}$ technical agar, Oxoid) (MESPA1). After $20 \mathrm{~h}$ of incubation at $30^{\circ} \mathrm{C}$, the colonies were cut out with a sterile cork borer having an internal diameter of $8 \mathrm{~mm}$ and moved to the centre of a ready-poured MESPA1.5 plate $(18 \mathrm{ml}$; containing $1.5 \% \mathrm{w} / \mathrm{v}$ technical agar) for the growth experiments.
Spore suspensions

To evaluate the effects of oxygen and carbon dioxide on the germination of $R h$. oligosporus the MESPA1.5 plates were inoculated in the centre with $20 \mu \mathrm{l}$ fresh spore suspension.

\section{Biomass monitoring}

At regular intervals petri dishes were removed in triplicate. After measurement of the radius of the colony, the agar plus mycelium and $300 \mathrm{ml}$ demineralized water were heated in a microwave oven until the suspension was boiling. The mixture was filtered through a preweighed filter (no. 595, Schleicher \& Schüll, Dassel, Germany). Subsequently the filters were dried for 2 days at $80^{\circ} \mathrm{C}$, before the mycelium dry weight was determined gravimetrically.

\section{Growth curves}

The growth curves based on the colony diameters and the natural logarithm of mycelium dry weight were fitted using linear regression to determine the radial growth rate and the specific growth rate. Parameters and the $95 \%$ confidence limits were calculated.

\section{Rotating drum fermentor}

Growth experiments on soaked and cooked soya beans were carried out in a 4.7-1 rotating drum fermentor described by de Reu et al. (1993). The soya beans were prepared as described previously by de Reu et al. (1993). During the experiments a discontinuous rotating scheme was used to avoid a temperature increase beyond $36^{\circ} \mathrm{C}$. After reaching the rotation temperature $\left(36^{\circ} \mathrm{C}\right)$ the system was rotated clockwise and counterclockwise for $1 \mathrm{~min}$ at $8 \mathrm{rpm}$. The slope of the temperature increase after the rotation period was used as an indirect method for measuring fungal activity.

\section{$\mathrm{pH}$ and formol titration}

A 20-g sample of fermented material was homogenized with $40 \mathrm{ml}$ water in a Waring blender for 1 min at maximum speed. The $\mathrm{pH}$ was measured in this suspension in duplicate using a pH meter (WTW, type 522; Weilheim, Germany) and a pH electrode (Schott-Geräte, type N61; Hofheim a. Ts., Germany). To this suspension $0.4 \mathrm{ml}$ $8 \mathrm{~mol} / 1 \mathrm{HCl}$ was added, $10 \mathrm{ml}$ demineralized water was added to $2 \mathrm{~g}$ suspension and this diluted suspension was titrated with $0.1 \mathrm{~mol} / 1$ $\mathrm{NaOH}$ to a constant $\mathrm{pH}$ of 8.5 . Subsequently, $5 \mathrm{ml}$ formaldehyde (37\%; catalogue no. 4003, Merck; pH 8.5) was added, and after 2 min the suspension was titrated with $0.1 \mathrm{~mol} / 1 \mathrm{NaOH}$ to $\mathrm{pH} 8.5$. The volume of $\mathrm{NaOH}$ that was required for this second titration was expressed as $\mathrm{ml}(0.1 \mathrm{~mol} / 1 \mathrm{NaOH}) / \mathrm{g}$ sample.

\section{Results}

\section{Effect of $\mathrm{O}_{2}$ on growth on MESPA1.5}

Figure 1 shows the biomass dry weight and the colony diameter of microcolonies at controlled concentrations of oxygen. The data represent averages of triplicate results. Owing to variations in the initial colony diameters $(3-8 \mathrm{~mm})$ and adaptation towards the agar, the 
radius of the colony did not increase during the first $4 \mathrm{~h}$; after this period the colony diameters increased linearly. The differences in biomass dry weight and colony diameters between $1 \%, 5 \%$ and $20.9 \%$ oxygen are relatively small. At lower oxygen concentrations $(0.5 \%$ and $0.001 \%$ oxygen $\mathrm{v} / \mathrm{v})$ the biomass dry weight hardly increased. When the natural logarithm of biomass dry weight was plotted against time, a linear increase was observed; this implies that the colonies did not reach the stationary phase before reaching the edge of the petri dish and therefore the logistic curve fitting was not used. Only the experiment at $20.9 \%$ oxygen

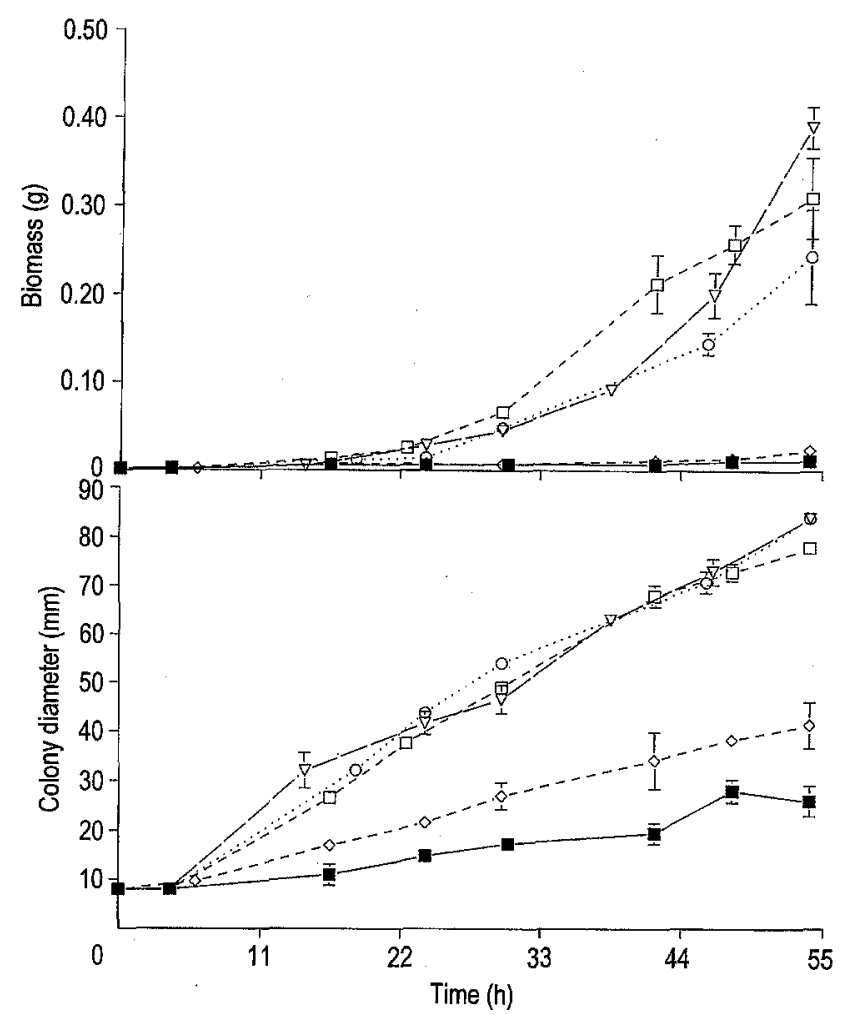

Fig. 1 Cumulative biomass dry weight (g) and colony diameter (mm) during growth of $R$ h. oligosporus on malt extract, soya peptone and technical agar (MESPA1.5) at constant oxygen concentrations at $30{ }^{\circ} \mathrm{C}$. $0.001 \%$ oxygen, $\diamond 0.5 \%$ oxygen, $\bigcirc 1.0 \%$ oxygen, $\nabla 5.0 \%$ oxygen, $\square 20.9 \%$ oxygen was in a phase between exponential growth and the stationary phase after $55 \mathrm{~h}$. The shape of the increasing microcolonies was perfectly circular. The experiments with the slope suspensions showed a more irregular colony pattern, and therefore it was more difficult to measure the radius of the colony and to determine $\mu_{\mathrm{rad}}$.

The radial growth rate $\left(\mu_{\mathrm{rad}}, \mathrm{Eq} .1\right)$ and the specific growth rate $\left(\mu_{\mathrm{x}}\right)$ were determined by linear regression of the colony diameter and the natural logarithm of the biomass respectively. In Table $1, \mu_{\mathrm{x}}$ and $\mu_{\mathrm{rad}}$ are shown for the experiments with various oxygen concentrations. A decrease in the oxygen concentration from $20.9 \%(\mathrm{v} / \mathrm{v})$ to $1 \%(\mathrm{v} / \mathrm{v})$ did not result in a significant decrease of the $\mu_{\mathrm{x}}$ and $\mu_{\mathrm{rad}}$. The growth rates decreased rapidly at oxygen concentrations below $1 \%(\mathrm{v} / \mathrm{v})$. Growth under extremely low oxygen concentrations $(<0.001 \% \mathrm{v} / \mathrm{v}$ oxygen) remained possible. Plotting the data in the Lineweaver-Burk plot resulted in a $V_{\mathrm{m}}$ of $0.11 \mathrm{~h}^{-1}$ and a $K_{\mathrm{m}}$ of $0.6 \% \mathrm{O}_{2}$.

\section{Effect of carbon dioxide on growth on MESPA1.5}

In Fig. 2, biomass dry weight and colony diameters are shown for the experiments with various amounts of carbon dioxide and $0.5 \%(\mathrm{v} / \mathrm{v})$ oxygen. The levels of carbon dioxide varied from 0 to $35 \%(\mathrm{v} / \mathrm{v})$ at a limiting oxygen level of $0.5 \%$. The amount of biomass dry weight increased when the carbon dioxide concentration increased from 0 to $5 \%(\mathrm{v} / \mathrm{v})$, whereas further increase from $5 \%$ to $35 \%$ carbon dioxide gave very low amounts of biomass. Similar trends are shown for the colony diameter. The differences between the colony diameters at $1 \%, 5 \%, 10 \%$ and $20 \%$ carbon dioxide are small, while the differences in biomass are more pronounced. This implies that the biomass density is more affected by the increased amount of carbon dioxide than the linear growth. At higher concentrations, carbon dioxide is therefore a growth-inhibiting factor.

Table 2 shows the effects of various concentrations of carbon dioxide in combination with $0.5 \%$ oxygen on $\mu_{\mathrm{x}}$ and $\mu_{\mathrm{rad}}$ of microcolonies and spore suspensions. Increasing the carbon dioxide from 0 to $5 \%(\mathrm{v} / \mathrm{v})$ resulted in an increase of $\mu_{\mathrm{x}}$ from $0.043 \mathrm{~h}^{-1}$ to

Table 1 Effect of oxygen on specific growth rate $\left(\mu_{\mathrm{x}}\right)$ and radial growth rate $\left(\mu_{\text {rad }}\right)$ for $R$ h. oligosporus on malt extract/soya peptone/agar inoculated with microcolonies and sporangiospore suspensions and incubated at $30^{\circ} \mathrm{C}$

\begin{tabular}{|c|c|c|c|c|c|c|}
\hline \multirow[b]{2}{*}{$\begin{array}{l}\text { Oxygen } \\
(\% \mathrm{v} / \mathrm{v})\end{array}$} & \multicolumn{4}{|c|}{ Microcolony } & \multicolumn{2}{|c|}{ Spore suspension } \\
\hline & $\begin{array}{l}\mu_{\mathrm{x}} \\
\left(\mathrm{h}^{-1}\right)\end{array}$ & $\begin{array}{l}95 \% \text { confidence } \\
\text { limits }\end{array}$ & $\begin{array}{l}\mu_{\mathrm{rad}} \\
(\mathrm{mm} / \mathrm{h})\end{array}$ & $\begin{array}{l}95 \% \text { confidence } \\
\text { limits }\end{array}$ & $\begin{array}{l}\mu_{\mathrm{x}} \\
\left(\mathrm{h}^{-1}\right)\end{array}$ & $\begin{array}{l}95 \% \text { confidence } \\
\text { limits }\end{array}$ \\
\hline$<0.001$ & 0.016 & $(0.011 ; 0.022)$ & 0.42 & $(0.33 ; 0.51)$ & 0.025 & $(0.011 ; 0.039)$ \\
\hline 0.5 & 0.043 & $(0.021 ; 0.066)$ & 0.67 & $(0.63 ; 0.70)$ & 0.028 & $(0.024 ; 0.033)$ \\
\hline 1 & 0.115 & $(0.072 ; 0.158)$ & 1.48 & $(1.26 ; 1.71)$ & 0.108 & $(0.086 ; 0.131)$ \\
\hline 5 & 0.108 & $(0.093 ; 0.124)$ & 1.46 & $(1.26 ; 1.64)$ & 0.095 & $(0.082 ; 0.107)$ \\
\hline 20.9 & 0.135 & $(0.093 ; 0.176)$ & 1.59 & $(1.52 ; 1.66)$ & 0.101 & $(0.091 ; 0.111)$ \\
\hline
\end{tabular}




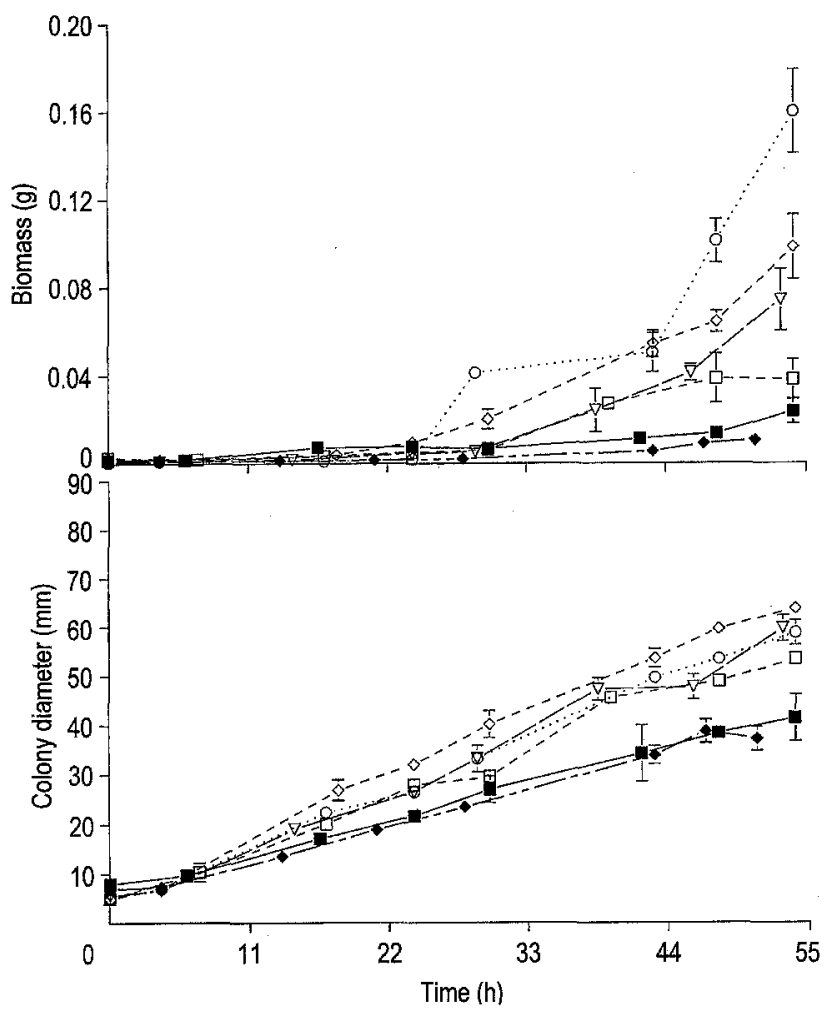

Fig. 2 Cumulative biomass dry weight (g) and colony diameter $(\mathrm{mm})$ during growth of $R h$. oligosporus on malt extract, soya peptone and technical agar (MESPA1.5) at constant carbon dioxide concentrations with $0.5 \%$ oxygen at $30^{\circ} \mathrm{C}$. $0.0 \%$ carbon dioxide, $\diamond 1.0 \%$ carbon dioxide, $\bigcirc 5.0 \%$ carbon dioxide, $\nabla 10.0 \%$ carbon dioxide, $\square 20.0 \%$ carbon dioxide, $\$ 35 \%$ carbon dioxide
$0.096 \mathrm{~h}^{-1}$. When oxygen was not limiting $(5 \% \mathrm{v} / \mathrm{v})$, carbon dioxide did not stimulate growth as can be seen by comparing $\mu_{\text {rad }}(1.39 \mathrm{~mm} / \mathrm{h}$ and $1.46 \mathrm{~mm} / \mathrm{h})$ and $\mu_{\mathrm{x}}$ $\left(0.111 \mathrm{~h}^{-1}\right.$ and $\left.0.109 \mathrm{~h}^{-1}\right)$.

Effect of $\mathrm{O}_{2}$ and $\mathrm{CO}_{2}$ on growth and fungal activity in the rotating drum fermentor

Table 3 shows the effects of gas compositions on various fungal activities during fermentation of soya beans with $R$ h. oligosporus in the rotating drum fermentor. As it is very difficult to measure biomass directly in solidstate fermentation in general and in agitated rotatingdrum fermentation systems in particular, temperature development, $\mathrm{pH}$ increase and increase in the degree of protein hydrolysis (as judged from the formol titration) were used as indirect parameters to determine the influence of various gas compositions on the fungal activity. The formol titration gives an indication of the hydrolysis of the proteins, by reacting with free $\alpha$-amino groups. The $\mathrm{pH}$ increase during this fermentation is based on a combination of ongoing processes, such as release of ammonia, release of carbon dioxide, assimilation of organic acids and changes in the buffering capacity of the soya beans.

Compared to the results at $20.9 \%$ oxygen (30 rotation periods and a slope of $3.5^{\circ} \mathrm{C} / \mathrm{h}$ ) lower amounts of oxygen had a strong influence on fungal activity, which was shown by the lower values for the temperature

Table 2 Effect of mixtures of carbon dioxide at $0.5 \% \mathrm{v} / \mathrm{v}$ oxygen on specific growth rate $\left(\mu_{\mathrm{x}}\right)$ and radial growth rate $\left(\mu_{\mathrm{rad}}\right)$ for $R h$. oligosporus on malt extract/soya peptone/agar inoculated with microcolonies and sporangiospore suspensions and incubated at $30^{\circ} \mathrm{C}$

\begin{tabular}{|c|c|c|c|c|c|c|}
\hline \multirow[b]{2}{*}{$\begin{array}{l}\text { Carbon dioxide } \\
(\% \mathrm{v} / \mathrm{v})\end{array}$} & \multicolumn{4}{|c|}{ Microcolony } & \multicolumn{2}{|c|}{ Spore suspension } \\
\hline & $\begin{array}{l}\mu_{\mathrm{x}} \\
\left(\mathrm{h}^{-1}\right)\end{array}$ & $\begin{array}{l}95 \% \text { confidence } \\
\text { limits }\end{array}$ & $\begin{array}{l}\mu_{\mathrm{rad}} \\
(\mathrm{mm} / \mathrm{h})\end{array}$ & $\begin{array}{l}95 \% \text { confidence } \\
\text { limits }\end{array}$ & $\begin{array}{l}\mu_{\mathrm{x}} \\
\left(\mathrm{h}^{-1}\right)\end{array}$ & $\begin{array}{l}95 \% \text { confidence } \\
\text { limits }\end{array}$ \\
\hline 0 & 0.043 & $(0.021 ; 0.066)$ & 0.67 & $(0.63 ; 0.70)$ & 0.028 & $(0.024 ; 0.033)$ \\
\hline 1.0 & 0.086 & $(0.072 ; 0.100)$ & 1.13 & $(1.03 ; 1.23)$ & 0.039 & $(0.015 ; 0.064)$ \\
\hline 5.0 & 0.096 & $(0.062 ; 0.129)$ & 0.98 & $(0.89 ; 1.06)$ & 0.094 & $(0.060 ; 0.128)$ \\
\hline 10.0 & 0.096 & $(0.082 ; 0.110)$ & 1.05 & $(0.90 ; 1.21)$ & 0.081 & $(0.061 ; 0.102)$ \\
\hline 20.0 & 0.070 & $(0.054 ; 0.084)$ & 0.94 & $(0.78 ; 1.09)$ & 0.068 & $(0.047 ; 0.089)$ \\
\hline 35.0 & 0.056 & $(0.044 ; 0.067)$ & 0.71 & $(0.64 ; 0.78)$ & 0.054 & $(0.044 ; 0.065)$ \\
\hline
\end{tabular}

Table 3 The influence of oxygen and carbon dioxide on the fungal activity of $R h$. oligosporus in the rotating drum fermentor. $\Delta p H, \Delta$ formol changes in $\mathrm{pH}$ and formol concentration respectively

\begin{tabular}{|c|c|c|c|c|c|}
\hline $\begin{array}{l}\text { Oxygen } \\
(\% \mathrm{v} / \mathrm{v})\end{array}$ & $\begin{array}{l}\text { Carbon dioxide } \\
(\% \mathrm{v} / \mathrm{v})\end{array}$ & Rotation period & $\begin{array}{l}\text { Slope } \\
\left({ }^{\circ} \mathrm{C} / \mathrm{h}\right)\end{array}$ & $\Delta \mathrm{pH}$ & $\begin{array}{l}\Delta \text { formol } \\
(\mathrm{ml} 0.1 \mathrm{M} \mathrm{NaOH} / \mathrm{g})\end{array}$ \\
\hline 0.1 & 0 & 0 & $<0.1$ & -0.06 & -0.02 \\
\hline 0.5 & 0 & 0 & $<0.1$ & 0.90 & -0.04 \\
\hline 2.5 & 0 & 2 & 0.6 & 1.12 & 0.10 \\
\hline 5 & 0 & 8 & 0.7 & 1.14 & 0.08 \\
\hline 5 & 10 & 16 & 0.8 & 1.71 & 0.14 \\
\hline 5 & 15 & 12 & 0.5 & 1.29 & 0.06 \\
\hline 5 & 35 & 6 & 0.6 & 1.37 & 0.09 \\
\hline 10 & 0 & 10 & 0.8 & 1.85 & 0.14 \\
\hline 20 & 0 & 30 & 3.5 & 1.29 & 0.20 \\
\hline 20 & 10 & 14 & 3.5 & 2.36 & 0.21 \\
\hline 20 & 15 & 18 & 2.0 & 1.03 & 0.24 \\
\hline 20 & 35 & 4 & 0.9 & 1.37 & 0.10 \\
\hline 40 & 0 & 43 & 5.5 & 1.40 & 0.20 \\
\hline
\end{tabular}


slope, less $\mathrm{pH}$ increase and less increase of the hydrolysis of proteins. Increasing the oxygen concentration from $20.9 \%$ to $40 \%(\mathrm{v} / \mathrm{v})$ had a significant effect on the heat production but did not result in increased $\mathrm{pH}$ and formol values.

When the carbon dioxide concentration increased from 0 to $10 \%$ an increase in fungal activity was observed as shown by the changes in $\mathrm{pH}$ and formol. A further increase from $15 \%$ to $35 \%$ resulted in a lower fungal activity. However, this effect was less strong than that following a decrease in the amount of oxygen from $20 \%$ to $2.5 \%$.

\section{Diseussion}

In this study we used microcolonies to standardize the initial conditions for the growth experiments under various atmospheric conditions. With this technique, the effects of the gas composition on the germination of $R h$. oligosporus sporangiospores was excluded. The latter effects were studied during parallel experiments with microcolonies and spore suspensions in the same incubator under the same gas composition.

On the basis of differences in the $95 \%$ confidence limits (Table 1) it is clear that the fitted values for the radial growth rates are more reliable than those for the specific growth rate. With a decreasing amount of oxygen, the band-width of the $95 \%$ confidence limits for the specific growth rate increased. This can be caused by the inaccuracy of the biomass determination at low values, for example, or the fact that the biomass increase is not yet exponential when oxygen is the limiting factor.

No significant differences were found in biomass dry weight between microcolonies and sporangiospore suspensions. Therefore the effect of oxygen on the germination of sporangiospores could not be measured using biomass increase. The number of germinated spores might be influenced by the oxygen concentration, as reported by Wells and Uota (1969), but this was not monitored in this study.

Once the spores were germinated it was expected that the values for $\mu_{\mathrm{x}}$ would be similar to those obtained for the microcolonies. Specific growth rates tend to be lower for the spore suspensions. These differences were small, however, and within the $95 \%$ confidence limits.

The increase in specific growth at increased carbon dioxide levels implies that carbon dioxide can stimulate growth when oxygen is limiting. Seaby et al. (1988) reported that the colony area increased when the carbon dioxide concentration in a mixture with air was increased from 0 to $5 \%$, but this does not automatically imply that the specific growth rate was increased as well. Therefore it is difficult to compare the data of Seaby with those obtained by us, as we have shown that colonies with the same radius could have a different amount of biomass. Carbon dioxide stimulation of the growth of fungi has been attributed to carbon dioxide fixation to pyruvate by pyruvate carboxylase, yielding oxaloacetate, through which pools of oxoacids in the Krebs cycle are replenished (Gadd 1988). This type of metabolism may be significant to some species of fungi when oxygen is growth-limiting, and when the carbon dioxide concentrations are not inhibitory. The growthstimulating effect of carbon dioxide was less pronounced when the level of carbon dioxide was increased from $10 \%$ to $35 \%(\mathrm{v} / \mathrm{v})$. However, at $35 \%(\mathrm{v} / \mathrm{v})$ carbon dioxide and $0.5 \%(\mathrm{v} / \mathrm{v})$ oxygen, growth was still observed. This effect was also seen by Paster and Menasherov (1985), who reported that carbon dioxide levels as high as $60 \%(\mathrm{v} / \mathrm{v})$ were not completely inhibitory for growth of Fusarium sporotrichioides if sufficient oxygen was present.

When the results for the model medium are compared with those from the rotating-drum fermentor it is clear that biomass formation on model medium is less sensitive towards lower amounts of oxygen than fungal activity in the bioreactor. In both systems, growth stimulation by carbon dioxide levels between $1 \%$ and $10 \%(\mathrm{v} / \mathrm{v})$ occurred. High concentrations of carbon dioxide inhibited the growth in both systems.

If non-aerated or non-agitated systems are used in solid-substrate fermentation, the decreasing amount of oxygen and the increasing amount of carbon dioxide might both act as growth limiting factors. Forced aeration is a tool to avoid such conditions, but excessive heat production is also stimulated by aeration. That is why, for optimization purposes, aeration and heat removal are both necessary in large-scale solid-substrate bioreactors employing $R h$. oligosporus.

Acknowledgements The authors wish to thank $H$. Vonk and $Y$. Zijerveld for their contributions to this research programme. This study was financially supported by Nutricia Research, Zoetermeer, The Netherlands.

\section{References}

Alvarez-Martinez LR (1987) Modeling fungal Rhizopus oligosporus growth on extruded corn by solid substrate fermentation. $\mathrm{PhD}$ Thesis, Colorado State University (Diss. Abst. Int. B49, 1284)

Gadd GM (1988) Carbon utilization, In: Berry DR (ed) Physiology of industrial fungi. Blackwell, Oxford

Hesseltine CW, Featherston CL, Lombard GL, Dowell VR Jr (1985) Anaerobic growth of molds isolated from fermentation starters used for foods in Asian countries. Mycology 77:390-400

Mitchell DA, Lonsane BK (1992) Definition, characteristics and potential. In: Doelle HW (ed) Solid-substrate cultivation. Elsevier, Barking, England

Mitchell DA, Doelle HW, Greenfield PF (1988) Improvement of growth of Rhizopus oligosporus on a model solid substrate. Biotechnol Lett 10:497-502

Nout MJR, Rombouts FM (1990) Recent developments in tempe research. J Appl Bacteriol 69:609-633

Okazaki N, Sugama S, Tanaka (1980) Mathematical model for surface culture of koji mould. J Ferment Technol 58:471-476 
Oriol E, Schettino B, Viniegra-González G, Raimbault M (1987) Solid-state culture of Aspergillus niger on support. J Ferment Technol 66:57-62

Paster N, Menasherov M (1985) Inhibition of T2 toxin production of high moisture corn kernels by modified atmospheres. Appl Environ Microbiol 54:540-543

Pirt SJ (1967) A kinetic study of the mode of growth of surface colonies of bacteria and Fungi. J Gen Microbiol 47:181-187

Rathbun BL, Shuler ML (1983) Heat and mass transfer effects in a static solid substrate fermentations: design of fermentation chambers. Biotechnol Bioeng 25:929-938

Reu JC de, Zwietering MH, Rombouts FM, Nout MJR (1993) Temperature control in solid substrate fermentation through discontinuous rotation. Appl Microbiol Biotechnol 40: 261-265
Seaby DA, McCracken AR, Blakeman JP (1988) Experimental determination of requirements for the growth of edible Rhizopus species for use in solid substrate fermentation. J Sci Food Agric 44:289-299

Soccol CR, Raimbault M, Pinheiro LI (1994) Effect of $\mathrm{CO}_{2}$ concentration on the mycelium growth of Rhizopus species. Arq Biol Technol (Curitiba) 37:203-210

Trinci APJ (1969) A kinetic study of the growth of Aspergillus nidulans and other fungi. $\mathrm{J}$ Gen Microbiol 57:11-24

Trinci APJ (1971) Influences of the width of the peripheral growth zone on the radial growth rate of fungal colonies on solid medium. J Gen Microbiol 67:325-344

Wells JM, Uota M (1969) Germination and growth of five fungi in low oxygen and high carbon dioxide atmosphere. Plant Pathol Hort 60:50-53 